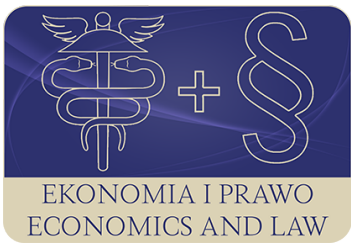

EKONOMIA I PRAWO. ECONOMICS AND LAW

Volume 18, Issue 3, September 2019

p-ISSN 1898-2255, e-ISSN 2392-1625

www.economicsandlaw.pl

ORIGINAL ARTICLE

received 19.07.2018; revised 31.07.2019; accepted 30.09.2019

Citation: Przesławska, G. (2019). Significance of uncertainty in explaining institutional change in Douglass C. North's approach. Ekonomia i Prawo. Economics and Law, 18(3): 331-346. doi:10.12775/EiP.2019.023.

\title{
Significance of uncertainty in explaining institutional change in Douglass C. North's approach
}

\author{
GABRIELA PRZESEAWSKA \\ University of Wroclaw, Faculty of Law, Administration and Economics, Institute of Economic \\ Science, ul. Uniwersytecka 22/26, 50-145 Wrocław, Poland \\ gabriela.przeslawska@uwr.edu.pl \\ (D) orcid.org/0000-0003-3949-5162
}

\begin{abstract}
Motivation: Studies on nature and effects of uncertainty in a non-ergodic world became in Douglass Cecil North's concept a starting point for explanation of economic changes mechanism. The origin of North's studies on uncertainty is related to one of key research problems relevant to the emergence of New Institutional Economics (NIE) approach, that is answering the question why some countries are rich and others poor. This problem, according to NIE representatives, cannot be satisfactorily explained in the framework of neoclassical paradigm based on assumptions of perfect information, ideal rationality of market actors and zero transaction costs.

Aim: The purpose of the article is to present D.C. North's concept of uncertainty as a source of beliefs and creating institutions ('rules of the game') which place human environment in order.

Results: North's breakthrough legacy is in emphasizing the role of human intentionality, growth in the stock of knowledge, as a result of human learning, and common cultural heritage in determining the direction and dynamics of economic changes. Considerations included in the article will enable proving the significance given by North to institutions in reducing uncertainty resulting from the nature of non-ergodic world and thus creating basic incentives for growth and evolutionary economic changes. Finally, the analysis conducted for that purpose in this article will show the original contribution of D.C. North's institutional-cognitive approach to the development of NIE (and economic theory in general) in explaining institutional conditions of development.
\end{abstract}


Keywords: uncertainty; mental models; players; institutions; institutional change JEL: D83, O43

\section{Introduction}

Reflections on the essence of uncertainty became in Douglass C. North's concept a starting point for explanation of economic changes mechanism.

The genesis of North's studies in the scope of uncertainty relates to one of the essential research problems relevant for the emergence of new institutional economics trend, that is answering the question, why certain countries are rich and others poor. This problem, according to New Institutional Economics (NIE) representatives, cannot be sufficiently explained in the framework of neoclassical paradigm based on assumptions of perfect information, ideal rationality of market actors and zero transaction costs.

Seeking the answers on the causes of differences between countries in terms of effectiveness and prosperity, the leading NIE representatives - Ronald Coase, Oliver Williamson, Douglass Cecil North and Elinor Ostrom - have created and applied in empirical studies the conceptual and analytical tools characteristic for the new approach such as transaction costs, ownership rights and contracts, presently referred to as 'golden triangle' of NIE, later supplemented with significant behavioural assumptions introduced by North in his 2005 work (Menard \& Shirley, 2014, pp. 3, 6).

The purpose of the article is to present D.C. North's concept concerning uncertainty as a source of formation of institutions ('rules of the game') which place human environment in order and - in this way, through the shaping of institutional framework - creating basic conditions for economic development.

The specified research task will be performed on the basis of literary studies, mainly based on the D.C. North's legacy. The logical analysis conducted in the article will show connections and dependencies that North saw between the occurrence of uncertainty and changes in physical and human environment, between uncertainty and creating institutions and beliefs (also vice versa) and between uncertainty and institutional change.

\section{The current state of knowledge, uncertainty in economic literature}

Uncertainty regarding the physical and human environment constitutes, according to North, the essential feature of a non-ergodic, that is unpredictable and constantly changing world ${ }^{1}$. At the very beginning of reflections concerning

${ }^{1}$ In economic literature it is assumed that North's concept, in which uncertainty derives from the nature of non-ergodic world, constitutes an important progress in the development of studies on this category. On this subject see Dequech (2006, pp.109-131). Rudolf Richter (2012) points out that North's approach to uncertainty includes epistemo- 
the significance of uncertainty in explaining institutional change, North refers to economic literature, mainly to the canonical work of Frank Knight (1921), in which he specifies the differences between uncertainty and risk. According to him, risk pertains to a condition in which there exists a probability of results, against which we can insure. Uncertainty, in turn, pertains to a condition in which such probability does not exist. North, intending to show the significance of human intentionality for limiting uncertainty by creating rules ordering environment, modifies and extends Knight's probabilistic definitions. For this purpose, he refers to an interpretation by Ronald Heiner (1983, pp. 560-595), according to whom uncertainty is 'the Origin of Predictable Behavior', which in North's concept means that it is uncertainty that is the source of rules formation and institutional change (North, 2005, p. 14).

As Mark Blaug (2000, pp. 67, 420, 714) reminds us, the problem of choice in conditions of uncertainty had previously been fragmentarily considered by Adam Smith and Alfred Marshall as well as John Maynard Keynes (1921), who emphasized non-probabilistic character of uncertainty, which in his words permeates the entire economic process. A significant contribution to the development of theory of choice in the conditions of uncertainty and risk was made by Kenneth Arrow (1970; Bochenek, 2012, pp. 46-63).

At this point, we will present views on uncertainty expressed by leading NIE representative, Oliver Williamson. He was mainly concerned with behavioral uncertainty. He associated the occurrence of uncertainty with the anticipated increase in transaction costs as costs of limited rationality (Williamson, 1975, p. 4) The uncertainty is - according to Williamson (1985) - an effect of unpredicted changes in consumers' preferences, lack of communication between decision makers, opportunistic behavior as well as failure to disclose, hiding or distorting information. The ways to solve these problems are court proceedings or adjustments in private order. However, in Williamson's view, the main role is played by improvements in organisations' performance, which is examined by transaction costs economics. The way to reduce them is optimization of institutions (Richter, 2012).

Williamson assesses institutional solutions (rules of the game) in respect of their influence on management effectiveness and privatization results and more broadly - in order to understand economic development and reform issues. As part of research on institutions he adopts two assumptions: (1) of social embeddedness of institutions and (2) of a condition concerning the attributes of human actors (Simon, 1985, pp. 293-303). In the analysis of human behavior, he employs research achievements of Herbert Simon, as well as Daniel Kahneman and Amos Tversky (1982, pp. 123-141) which show that in the process of making decisions by individuals in conditions of uncertainty there are cognitive limitations, which means that institutions are not objective. Conclusions derived from the achievements of evolutionary psychology and evolutionary an-

logical aspect concerning the nature of economic science, which according to non-ergodicity hypothesis, cannot be an exact science. 
thropology are used by Williamson (1998, pp. 75-79) in research into the governance structure effectiveness in the pursuit of reducing transaction costs. In this context, he notes that if the ability to recruit individuals capable of making choices under conditions of uncertainty outside the organization is limited, then the solution to the problem is the responsibility of the organization itself. The effective adjustment of various competences of individuals to the assigned tasks will be carried out through specialization, i.e. by dividing complicated tasks into parts and, after their completion, reassembling together.

Uncertainty in F. Knight's sense, understood as lack of knowledge of what future will bring, is the basis of explaining institutions' effectiveness adopted by other NIE researchers. Searching for ways to increase economic efficiency of institutions by reducing uncertainty constitutes a certain change of approach in comparison with the previous method of assessing the efficiency of institutions, mainly based on their abilities to minimize transaction costs (Richter, 2012). The ways to limit uncertainty, according to Rudolf Richter, are not only adaptive abilities of institutions (rules of the game) in response to unforeseen events but also common beliefs of actors, which are reflected in corporate culture as well as skills and social responsibility of political and business leaders. Richter (2012, p. 4) argues that in assessing the economic efficiency of the institutions, understood as adaptive efficiency, i.e. involving the reduction of uncertainty in the sense of Knight, it is also important to refer to the effectiveness of specific institutional alternatives. In establishing institutions, one should refer to the natural laws formulated by Hume ${ }^{2}$ and take into account the rules of competition (open society, open markets). Geoffrey Hodgson, a representative of institutional economics and evolutionary economics, notes that the inclusion of theoretical and empirical phenomena of uncertainty in research would enable the development of a more dynamic approach in economics than the static approach of transaction costs economics. As he argues, the recent crisis and failure of the theory of economics in the field of prediction has led economists to recognize the need to explore the realities of the modern capitalist economy to a wider extent than before. If economic models are to be predictive and not only heuristic, the phenomenon of uncertainty should also be modeled. According to Hodgson (2011, pp. 159-175), the fundamental limitations of modeling in economics arise from the failure to include in the analysis the unsolvable problems of uncertainty, complexity and openness of the economic system that occur in the real world.

2 Three Fundamental Laws of Nature: "that of the stability of possession, of its transference by consent, and of the performance of promises' (Hume,1969, p. 578). 


\section{The research process}

\subsection{Uncertainty according to North}

Economists studying progress in the development of new institutional economics underline that the leading representatives of this trend, the Nobel Memorial Prize in Economics laureates: Ronald Coase, Douglass C. North, and Oliver Williamson, have created and developed innovative conceptual and analytical tools that have enabled the development of empirical research (Menard \& Shirley, 2014 , p. 3$)^{3}$. This part of the article concerns North's contribution to improving NIE theory and methodology by creating a dynamic theory of economic change using historical, cultural and institutional-cognitive context. From the point of view of North's contribution to the theory of economics in general, analysis of economic change, included in the economic theory of choice, is innovative. However, in contrast to neoclassical economics, a starting point when making decisions and creating economic order was not the individual's rationality but uncertainty resulting from the nature of a non-ergodic world. As part of creating the theory of operation of economy in time and explanation of making choices in conditions of uncertainty in a complex human environment, North (2005, pp. 11-14) uses the output of other fields, mainly economic history and cognitive science, which allow the understanding of the principles of ordering the environment to reduce uncertainty. He devotes most attention to the theory of cognition in order to emphasize the role of the mind, the process of learning and gathering knowledge as the basic conditions for creating rules that increase the predictability of the environment. These rules are institutions, which 'by channeling choices into a smaller set of actions (...) can improve the ability of the agent to control the environment'.

North, analyzing economic history, reminds us how people were increasing the predictability of physical environment and reducing the associated uncertainty. An example is, among others, the development of marine insurance in the $15^{\text {th }}$ century as a result of increasing information on shipping, which took place in the condition of given stock of knowledge. Introducing insurance in shipping allowed converting uncertainty into risk and contributed to development of international trade. Another way of reducing uncertainty resulting from evolving physical environment was increasing the stock of knowledge in conditions of the already existing institutional framework. In this case - despite the absence of incentives generated by the unaltered institutional framework - the accumulation of knowledge was due to human creativity and innovativeness as well as changes in production factors prices. A crucial role in reducing uncertainty resulting from the non-ergodic nature of environment was played - in North's view - by alteration of institutional framework.

${ }^{3}$ On this subject in Polish economic literature see, among others: Godłów-Legiędź (2010, pp. 1-202), Stankiewicz (2005, pp. 1-121) or Wilkin (2016, pp. 1-262). 
The change that took place involved altering the structure of incentives to act, as a result of which the predictability of environment increased. The history of the Western world shows that due to the institutional change manifesting itself by the establishment of legal enforcement of contracts, patent rights, creation of judicial system, there was a reduction in transaction costs and uncertainty, which ultimately enabled economic development. Uncertainty, as North (2005, pp. 16-18) notes, results to a large extent from new challenges. The fundamental novelty in the historical development of economies was the transition from the stage of personal exchange to impersonal exchange. Studies have shown that impersonal exchange institutions were based on the cumulative cultural heritage of societies. It was the historically collected cultural heritage that determined the ways to solve new problems and thus the increase of predictability of environment. At the same time, North (2005, pp. 21, 165) points out that institutional changes increasing market efficiency may, particularly in third world countries, generate new and previously unknown manifestations of uncertainty. They are a consequence of changes in income distribution, emergence of winners and losers and are related to political instability, which often accompanies the change taking place.

\subsection{Beliefs}

A significant element of North's theory, allowing the understanding of the process of economic change, are the beliefs, both of individuals and those shared commonly, that is systems of beliefs. The process of forming beliefs, the determinants of their change are part of analysis, which explains the way in which institutions are formed to reduce uncertainty of human environment. It was the belief system development - in North's view - that generated institutional changes in political, economic and social spheres.

In discussing transformation of institutions and beliefs reducing the uncertainty of physical environment, and then the shaping of beliefs and institutions useful in reducing uncertainty created by social environment, North subjects them to historical comparisons. As he writes, it is 'the key to understanding the process of change' (North, 2005, p. 100). The breakthrough changes in political, social and economic organization - as historical experience shows - have come together with a fundamental transformation of the cultural environment that has taken place with the transition from personal exchange to impersonal exchange. North's analysis of institutions and beliefs, relevant to the compared stages in the historical development of the world, showed that while in former collectivist cultures norms and beliefs based on status and coercion were in force, in an individualistic culture, appropriate for well-developed markets, the reaction to the challenges of an ever-changing human environment was the emergence of an institutional structure composed of formal rules and mechanisms for their enforcement (North, 2005, pp. 100-102). 
Beliefs and well-shaped institutions, which in the evolutionary process have retained their ability to survive, act as a motivating system for obtaining desired economic outcomes. Together they make up the culture. Describing the significance of culture as 'intergenerational transfer of norms, values and ideas', North refers to the works of Edwin Hutchins and Brian Hazelhurst (1992, p. 690), who define 'the learning of past generations transmitted as culture into the belief structure of present generations' as the artifactual structure. The most important 'carrier' of the artifactual structure are 'the informal constraints embodied in norms of behavior, conventions, and self-imposed codes of conduct', which subsequently - as a reflection of that heritage - are transformed into formal rules established by society. In the analyzed context, North assumed that 'human intentionality is not spontaneous' but conscious, which means that humans can 'shape their future' and 'structure human interaction'4. This means, according to North (2005, pp. 51-52), that path dependence - as the way in which 'the past connects with the present and future' is not, as it is misunderstood, 'inertia' and sign of bad performance of institutions but only 'the constraints on the choice set in the present that are derived from historical experiences of the past'. North sees the path dependence not only as 'a fundamental factor in the continuity of a society' but also as 'the limits to change'.

\subsection{Cognitive process, mental models, the role of players}

North's research on uncertainty, its sources and ways of reducing, left a lasting mark in the development of science. As already mentioned, the effect of North's research is an important contribution to cognitive science - the theory of cognition, thanks to the emphasis on the cognitive competence of players in explaining reality and creating institutional changes. As he noted, the purpose of his research was to explain in what way people control (order) their environment in the event of economic change. Controlling the environment involves reducing the uncertainty of the human environment characterized by enormous complexity as a result of the ongoing change (North, 2005, pp. 1-2). North explained that the way to reduce uncertainty in human environment is to apply science and technology so that people gain power over the environment. The interconnections between science and technology make it possible to change the human environment by establishing an institutional matrix that is a set of formal rules and informal constraints. At the same time, he noticed that "the reality of a political-economic system is never known to anyone', first 'a positive model of the way the system works and a normative model of how it should work'

${ }^{4}$ North's position is different from the view of F.A. Hayek (1960, p. 40), who - while also admitting that culture is 'the transmission in time of our accumulated stock of knowledge' - at the same time believed that this absorption takes place in a spontaneous process, due to the limited understanding of the complex nature of social interaction by people. Richter (2012) notes that North understood institutions as human creations, whether they are deliberately designed or an effect of spontaneous evolution. 
must be constructed. Thus, the dominant beliefs of the political and economic entrepreneurs must be converted into policies and creation of the framework of formal and informal institutions that will stimulate the economy's efficiency (North, 2003, p. 6) .

According to North, transaction costs - 'frictions' - occur not only in the exchange process but also in the cognitive process as the costs of perception and information processing. The task of the institutional system is to reduce the uncertainty associated with change by constructing institutions that facilitate the flow of information and thus reduce the costs of information processing and acquisition of knowledge by individuals (Denzau \& North, 1994, pp. 3-31; Hardt, 2005, p. 13). In North's concept, the cognitive process and the creation of a new order as a result of ongoing change take place in several successive sequences: perception of reality induces a set of beliefs, beliefs are induced in a set of institutions that shape new order, which in turn results in a change of policies and revision of norms.

North (2003, pp. 9-13), like Hayek, recognized the role of ideas in making choices. He explained how to make choices in the event of changes in the environment, when the future fundamentally differs from the past and the present, when old methods and patterns cannot be duplicated and the existing institutions inhibit change. In this situation, as he noted in particular, more radical changes are determined by the requirements of economic growth ${ }^{6}$.

In analyzed context, North (2005, p. 59) had already emphasized that the condition for change in the situation of limited resources is constant interaction between institutions and organizations. Competition between organizations forces the necessity of investments in skills and knowledge in order to survive. The resources of acquired skills and knowledge become a determinant of evo-

${ }^{5}$ J. Campbell (2010), analyzing the evolution of literature concerning institutional changes, notices that modern theories to a greater extent than earlier ones (which rather appreciated the significance of technical and functional imperatives) emphasize the activity of actors in stimulating change. Considerations in this area are carried out using the concepts of struggle, conflict and negotiation. At present, institutions are viewed not only as constraints limiting the range of choice in decision-making but also as flexible resources and opportunities that actors can use to make a change, however in an evolutionary and incremental manner. Contemporary researchers of institutions still emphasize the usefulness of the path dependence concept in explaining the process of change and its constraining as well as the influence of political and economic conditions, which make institutions a multidimensional phenomenon. In this context, complexity, interconnectedness and complementarities of institutions are considered, particularly the impact of transnational institutions on national institutions and - in this sense - on the process of institutional change.

${ }^{6}$ Researchers of institutional economy recognize that in North's works (2005) the twoway causality between institutions and economic development is visible. The examples from economic history analyzed by North prove that the causality takes place both in the influence of institutions on development and vice versa - through the impact of economic development on creating and changing institutions. On this subject see: Chang (2011, pp. 595-613) vs Shirley (2011). 
lutionary perception of new opportunities and choices by organizations, and as a consequence the incremental change of institutions. The ability of societies to adapt flexibly to new challenges ('shocks') through the development of institutions, enabling the solution of problems related to the new reality and entering the path of growth is, according to North, a sign of adaptive efficiency.

In emphasizing the significance of cognitive models in the process of institutional change, North believed that cognitive rules are formed as a result of individual, i.e. unitary processes of learning and acquiring knowledge. At present, opinions are being held that cognitive rules are rather social constructs, shaped in social interactions. In this sense, they are a result of 'distilled' beliefs and also a summary of social experiences, which in the form of information and social rules are conveyed to decision-making individuals (Greif \& Mokyr, 2017, p. 25).

To sum up, North's theory is an attempt to show in a comprehensive manner the interdependencies in time between organizations, institutions, competition, incentives and cognitive models of players, which allow the understanding of institutions' evolution, i.e. a process of institutional change (North, 2005, p. 59; Weingast \& Levi, 2019). The most important aspect of institutional analysis and a starting point to explain the institutions' influence on economic outcome was for North the analysis of cognitive processes. According to this concept, it is above all the changes in the sphere of cognition, caused by uncertainty, that determine institutional changes, and then generate changes in economy. As he wrote: 'in time, it became clear that changing cognition and beliefs was important to institutional change' (Greif \& Mokyr, 2017; North, 2005). The processes of increasing knowledge in the field of cognitive science and its use in institutional analysis have been jointly called by North and his collaborators 'cognitive institutionalism' (Mantzavinos et al., 2004, p. 75).

North was skeptical about the views of libertarians, who saw the sources of economy's successes mainly in efficient property rights and the rule of law, without the necessity of institutional adjustments (North, 2005, p. 122). Also, the growth of stock of knowledge and the development of science and technology does not automatically ensure successes (North, 2005, pp. 72-73). Although he recognizes that 'the stock of knowledge the individuals in a society possess is the deep underlying determinant of the performance of economies and societies' (North, 2005, p. 63), he notes that the condition for development is the shaping of complex institutional structure that will enable the integration of dispersed knowledge, its absorption, accessibility and solving problems (North, 2005, pp. 72-73). As he writes, in economic evolution 'it is the intentionality of the players as expressed through the institutions they create which shapes performance' (North, 2005, p. 66).

In this context, North emphasizes that the problems of poorly functioning economies result mainly from the lack of adjustments of the institutional structure, i.e. the existing formal institutions and informal constraints, to the challenges that the economies face. One of such challenges is the ubiquitous uncertainty. The institutional structure in less developed countries man- 
ifests itself in existing of organizations characterized by inertia and blocking any progressive changes in fear of losing the current privileges by its members. The weakness of structures existing in those countries may be also the inherited and deeply rooted systems of beliefs, inadequate to new challenges, as well as informal rules which limit competition and freedom of political players in making a change. This means that order or disorder in economy are - in North's view - an effect of institutional structure evolving in time. In the face of shocks and crises, only these societies will survive that as a result of evolution have shaped an institutional structure based on the cultural heritage of stable institutions capable of restoring order (North, 2005, p. 115). In his theory, North (2005, p. 167) sees the limits of adaptive efficiency. The uncertainty of successful institutional adaptation may result from the double nature of human consciousness. It is because the consciousness constitutes both a source of human creativity and of superstitions, dogmas, religions. As he writes: "non-rational beliefs get combined with various cultural attributes to produce particular anti-social attitudes'. The limit of adaptive efficiency may be also set by the uncertainty if players who understand nature of the problems and have a vision of desired changes to institutions will obtain from the state an opportunity to act in the role of decision-makers and create an institutional structure including incentives to development.

According to North (2005, pp. 167-169), the fundamental problems associated with the evolving human environment require understanding of the dependencies between the institutional, technological and political conditions. In this context, he emphasizes that adaptive efficiency is a dynamic state. Like Hayek, he thinks that institutional adaptations that do not ensure the economies' ability to solve problems related to uncertainty should be eliminated. The world's economic history indicates that 'development was more good fortune than intent'. The institutional change is caused by evolution of human beliefs, which is the condition of economic change. This means that institutions must reflect the cultural heritage and beliefs which are subject to evolution and long processes of acquiring knowledge. Thus, the changes take place gradually and are of incremental nature (North, 2005, p. 64) ${ }^{7}$.

\subsection{The role of the state in the process of institutional change}

North (2005, pp. 78-79) repeatedly stresses in his works that the condition for economic change leading to well-being is the accompanying institutional change. Economic change is a change in human well-being expressed in quantitative indicators regarding income changes and the unmeasurable parameters of other important aspects of improving social well-being. North emphasizes that the increase in human well-being is determined by the necessary growth

7 Richter (2012, pp. 26-27) reminds us after Karl Popper (1957) that the use of radical methods in order to make a change - through social engineering - is of Utopian nature and will not ensure lasting results. 
in the stock of knowledge, but above all by the result of the interaction between the stock of knowledge, institutions and demographic factors that together shape the economic change. The institutional change, generalizing this interplay, is related to the construction of such an institutional framework, i.e. a combination of formal rules and informal constraints, the interplay of which will ensure an increase in the economy's efficiency and a desired level of well-being that is right for economic change. North tries to explain what combination of rules of the game will probably provide the desired outcomes. He recognizes the existence of difficulties in seeking to organize the human environment in order to reduce uncertainty. Difficulties are not only the result of human fallibility, but also of poor organization of markets, which means that players do not compete via prices but through non-market methods. The players also often act within the constraints of path dependence, that is, the past-inherited combination of beliefs and institutions that are inadequate to the new reality. In such conditions, the potential Smithian result cannot ensue (Smith, 1776) ${ }^{8}$.

In the analyzed context, North points out the difficulties related to movement from personal to impersonal exchange, which pose 'a fundamental obstacle to realizing the potential envisioned by Adam Smith when he viewed the wealth of nations as being a function of the size of markets'. North (2005, p. 84) reminds us that these problems were previously ignored by neo-classical economics due to the omission of 'explicit institutional analysis' in order to explain them. In his view, to 'realize Smith's beneficent result' caused by significance of markets as well as specialization and division of labor as conditions for formation of such markets, the "novel institutional and organizational connections' are required in order to solve problems resulting from 'the public goods attributes, externalities, and information asymmetries that prevent the price

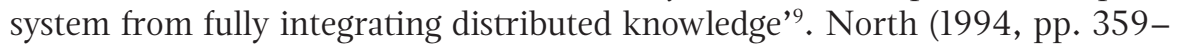

${ }^{8}$ In his institutional-cognitive theory of economic development North uses such categories as: transaction costs, institutions, credible commitments, beliefs and cognitive factors. However, as Weingast \& Levi (2019) notice, North in his studies on the sources of economic growth views, like Adam Smith, the problem of sources of wealth of nations as a central research problem, seeking answers, why some countries are rich and the others poor? B. Weingast (2016) emphasizes the significance of institutions in the development of world economy after 1880, referring to the Deirdre McCloskey (2016) work. He shares McCloskey's views on the role of ideas of liberty, equality and the rule of law as causes of 'great enrichment'. At the same time, he argues that the ideas are not self-sufficient; history knows many cases where ideas were not implemented. Thus, he thinks that the condition for implementing ideas is their internalization through creating institutions together with mechanisms of their enforcement.

9 A reference to the message of Adam Smith on the significance of exchange in increasing productivity of the economic system can be also found in the works of Ronald Coase, who was the first to introduce transaction costs to economic analysis. Coase (1998, p. 73) defines the costs of exchange as transaction costs explicite, arguing that the lower the exchange costs, the more specialization there will be and the higher system productivity. 'But the costs of exchange depend on the institutions of a country: its legal system, its political 
368) emphasizes that the structuring of necessary institutional framework ensuring the development of efficient markets will not take place automatically due to the features of dynamic world, i.e. changes in 'technology, information costs, and politics'. This task must be carried out by the state, but the one limited from temptations of arbitrariness, excessive power and 'preying on the market' by crafting the necessary political institutions and guarantees related to the nature of public goods ('in particular property rights and rule of law - they are traditionally created through the political system' $)^{10}$. The institutions which secure the general interest and greater efficiency of the political markets include both formal rules, i.e. mutual control of the authorities, as well as informal constraints that encourage players to behave in a manner that guarantees the achievement of the assumed goals (North, 2005, p. 68) .

\section{Conclusion}

The uncertainty and non-ergodicity of the world are the starting point and basic conditions for institutional change in D.C. North's dynamic theory of economic change. Uncertainty of human environment is in North's concept a source of creation of institutions - rules of the game that - through limiting the range of choices - allow controlling the environment, increasing its probability, defeating uncertainty and converting it into risk. In this way, creating institutions and new beliefs, that is the shaping of institutional framework becomes a fundamental condition for civilization development and economic change. North, in his economic evolution theory, emphasizes the importance of human intentionality, learning processes and acquiring knowledge in reducing uncertainty.

North made an important contribution to methodology and development of modern institutional economy through formulating the concept of adaptive efficiency as the measure of institutions' efficiency and the criterion of economic system's assessment, understood as the ability of institutional environment to adapt in conditions of uncertainty and generate incentives to solve problems in the development process.

Considerations included in the article showed the significance given by North to institutions and cognitive factors in reducing uncertainty resulting from the nature of non-ergodic world and thus creating basic incentives for growth and evolutionary economic changes. Finally, the analysis conducted for that purpose in this article proved the original contribution of D.C. North's in-

system, its social system, its educational system, its culture, and so on. In effect it is the institutions that govern the performance of an economy'.

${ }^{10}$ On the subject of tasks for the state in creating institutional system in Polish economic literature see: Sukiennik et al. (2017, pp. 122-143) and Wilkin (2016, pp. 221-232).

11 The inefficiency of political mechanisms as the cause of institutional uncertainty and the ways to reduce it according to the concept of new political economy were described by Ząbkowicz (1998, pp. 719-730). On this subject, see also: Przesławska (2006a, pp. 35-48; 2006b, pp. 309-320). 
stitutional-cognitive approach to the development of NIE and economic theory in general, due to the more complex explanation of economic change taking into account the influence of institutional factors: political, normative and the role of incentives and beliefs. The article indicates the following examples of North's heritage, which constitute an original and lasting value in the development and diversity of economic theory. They concern a modification of the idea of rationality, economic effectiveness and also the importance of institutions, including the role of the state, in the process of economic changes and in economic performance through time. North's achievements in the area of historical analysis of institutions enriched the explanandum of economics (a set of examined events) by taking advantage of the heritage of other social sciences, i.e. economic history, political sciences and cognitive science, in the analysis.

Taking the significance of institutions and institutional conditions of economic change into account by North in his analysis extended the knowledge of factors decisive in the evolution of markets and the development of economies through time. North's studies on the scope and role of institutions in shaping institutional environment as an important growth factor became an inspiration for the further theoretical and empirical research in the framework of development economics. It is worth mentioning that the World Economic Forum, considering institutions (i.e. the rules of the game in force) a basic condition for the countries' competitiveness, bases on the D.C. North's definition of institutions in its work and reports (World Economic Forum, 2015, p. 44).

In the article, it is highlighted that the institutional theory of long-term economic and political changes is presently considered a direct continuation of the Adam Smith's work on the sources of wealth of nations, that is causes of prosperity of certain countries and poverty of others. North, referring to that work, emphasizes the role of appropriate political environment, proper regulation and enforcement of good law in the development of markets, which is to be guaranteed by institutions. As the literature indicates, such approach is now considered standard and defined as 'good governance' (although it was marginalized in the eighties). Francis Fukuyama (2016, p. 89) wrote that the renewed recognition of the significance of effective governance by economists and politicians at the beginning of the nineties was influenced by works of D.C. North who highlighted the role of state in laying foundations for trade, and in particular the importance of property rights in promoting growth.

In the context of the subject of the article, the originality and significance of the institutional-cognitive North's theory, in which the category of uncertainty is considered a source of creating institutions and institutional and economic change, was underlined. North's approach constitutes a substantial progress in development of studies concerning that category. As it was indicated, further theoretical and empirical studies on the phenomenon of uncertainty would enable devising a more dynamic approach in economics than the static approach specific for transaction costs economics. Modeling the phenomenon of uncer- 
tainty would allow fuller examination of the reality of modern economy and thus strengthening the cognitive and predictive function of economics.

In the article, it is proved that North's concept on the role of ideas, beliefs, culture, path dependence, intentionality of players in the process of making choices in the conditions of uncertainty is an example of North's constructive approach to the nature of human learning because it modifies the assumption of rationality which forms the basis of the mainstream economic theory. In this way, the institutional-cognitive approach brings closer the knowledge of possibilities and speed of institutional and economic changes, which according to North are gradual and incremental.

To sum up the evaluation of the influence of North's heritage on the development and diversity of economics, the words of Ronald Coase (1999, pp. 3-6) about the significance of NIE and relations between mainstream economics and new institutional economics, of which North is a notable representative, may be used: "we will not replace price theory (supply and demand and all that) but will put it in a setting that will make it vastly more fruitful'.

\section{References}

Arrow, K.J. (1970). Eseje z teorii ryzyka. Warszawa: PWN.

Blaug, M. (2000). Teoria ekonomii: ujęcie retrospektywne. Warszawa: PWN.

Bochenek, M. (2012). Ryzyko i niepewność w naukach ekonomicznych: rozważania semantyczne. Ekonomia. Economics, 4(21).

Campbell, J.L. (2010). Institutional reproduction and change. In G. Morgan, J.L. Campbell, C. Crouch, O.K. Pedersen, \& R. Whitley (eds.), The Oxford handbook of comparative institutional analysis. Oxford: Oxford University Press. doi:10.1093/oxfordhb/9780199233762.003.0005.

Chang, H.J. (2011). Reply to the comments on 'Institutions and economic development: theory, policy and history'. Journal of Institutional Economics, 7(4). doi:10.1017/S174413741100035X.

Coase, R.H. (1998). The new institutional economics. American Economic Review, 88(2).

Coase, R.H. (1999). The task of the society: opening address to the annual conference of ISNIE. Newsletter of the International Society for New Institutional Economics, 2(2).

Denzau, A.T., \& North, D.C. (1994). Shared mental models: ideologies and institutions. Kyklos, 47(1). doi:10.1111/j.1467-6435.1994.tb02246.x.

Dequech, D. (2006). The new institutional economics and the theory of behaviour under uncertainty. Journal of Economic Behavior \& Organization, 59(1). doi:10.1016/j.jebo.2004.03.012.

Fukuyama, F. (2016). Governance: why do we know, and how do we know it? Annual Review of Political Science, 19(1). doi:10.1146/ annurev-polisci-042214-044240. 
Godłów-Legiędź, J. (2010). Wspótczesna ekonomia. Ku nowemu paradygmatowi. Warszawa: C.H. Beck.

Greif, A., \& Mokyr, J. (2017). Cognitive rules, institutions, and economic growth: Douglass North and beyond. Journal of Institutional Economics, 13(1). doi:10.1017/s1744137416000370.

Hardt, Ł. (2005). Instytucje a koszty transakcyjne w nowej ekonomii instytucjonalnej. Gospodarka Narodowa, 197(1-2). doi:10.33119/gn/101504.

Hayek, F.A. (1960). The constitution of liberty. Chicago: University of Chicago Press.

Heiner, R. (1983). The origin of predictable behavior. American Economic Review, 73(4).

Hodgson, G.M. (2011). The eclipse of the uncertainty concept in mainstream economics. Journal of Economic Issues, 45(1). doi:10.2753/jei0021-3624450109.

Hume, D. (1969). A treatise of human nature. E.C. Mossner (ed.), Harmondsworth: Penguin Books.

Hutchins, E., \& Hazelhurst, B. (1992). Learning in the cultural process. In: C.G. Langston (ed.), Artificial life II. Redwood City: Addison-Wesley.

Kahneman, D., \& Tversky, A. (1982). On the Study of Statistical Intuitions. Cognition, 11(2). doi:10.1016/0010-0277(82)90022-1.

Keynes, J.M. (1921). A treatise on probability. London: Macmillan.

Knight, F.H. (1921). Risk, uncertainty, and profit. New York: Houghton Mifflin.

Mantzavinos, C., North, D.C., \& Shariq, S. (2004). Learning, institutions, and economic performance. Perspectives on Politics, 2(1). doi:10.1017/ S1537592704000635.

McCloskey, D. (2016). Bourgeois equality: how ideas, not capital or institutions enriched the world. Chicago: University of Chicago Press.

Menard, C., \& Shirley, M.M. (2014). The contribution of Douglass North to new institutional economics. In S. Galani, \& I. Sened (eds.), Institutions property rights and economic growth: the legacy of Douglass North. Cambridge: Cambridge University Press.

North, D.C. (1994). Economic performance through time: the limits to knowledge. American Economic Review, 84(3).

North, D.C. (2003). Understanding the process of economic change. Retrieved 31.07.2019 from http://pdf.usaid.gov.

North, D.C. (2005). Understanding the process of economic change. Princeton: Princeton University Press.

Popper, K. (1957). The poverty of historicism. London: Routlede.

Przesławska, G. (2006a). Ekonomiczna rola państwa w ujęciu nowej ekonomii politycznej. Ekonomia i Prawo. Economics and Law, 2(1). doi:10.12775/EiP. 2006.001.

Przesławska, G. (2006b). Konstytucyjne ograniczenia działań politycznych w sferze finansów publicznych w koncepcji Jamesa M. Buchanana. Polityka Gospodarcza, 13. 
Richter, R. (2012). Efficiency of institutions: from the perspective of new institutional economics with emphasis on Knightian Uncertainty. SSRN Electronic Journal. doi:10.2139/ssrn.2105604.

Shirley, M.M. (2011). What should be the standards for scholarly criticism? Journal of Institutional Economics, 7(4) doi:10.1017/S1744137410000469.

Simon, H. (1985). Human nature in politics: the dialogue of psychology and political science. American Political Science Review, 79(2). doi:10.2307/1956650.

Smith, A. (1776). An inquiry into the nature and causes of the wealth of nations. London: Printed for W. Strahan and T. Cadell.

Stankiewicz, W. (2005). Ekonomika instytucjonalna: zarys wyktadu. Warszawa: Prywatna Wyższa Szkoła Biznesu i Administracji.

Sukiennik, J., Dokurno, Z., \& Fiedor, B. (2017). System instytucjonalnej równowagi a proces zmian instytucjonalnych z perspektywy zrównoważonego rozwoju. Ekonomista, 2.

Weingast, B.R. (2016). Exposing the neoclassical fallacy: McCloskey on ideas and the great enrichment. Scandinavian Economic History Review, 64(3). doi:10.1080/03585522.2016.1233134.

Weingast, B.R., \& Levi, M. (2019). Douglass North's theory of politics. PS: Political Science \& Politics, 52(2). doi:10.1017/s1049096518002111.

Wilkin, J. (2016). Instytucjonalne i kulturowe podstawy gospodarowania: humanistyczna perspektywa ekonomii. Warszawa: Scholar.

Williamson, O.E. (1975). Markets and hierarchies: analysis and antitrust implications. New York: Free Press.

Williamson, O.E. (1985). The economic institutions of capitalism. New York: Free Press.

Williamson, O.E. (1998). The institutions of governance. American Economic Review, 88(2).

World Economic Forum. (2015). The global competitiveness report 2015-2016. Retrieved 01.01.2016 from http://www3.weforum.org.

Ząbkowicz, A. (1998). Państwo a źródła niepewności instytucjonalnej. Ekonomista, 5-6.

\section{Acknowledgements}

Author contributions: author has given an approval to the final version of the article.

Funding: this research was funded by the University of Wroclaw, Faculty of Law, Administration and Economics statutory sources.

Note: the results of this study were presented at Second Scientific Conference Institutions: theory and practice (June, 19-20 2018, Torun, Poland). 